\title{
MENGGAGAS PENGETAHUAN BERBASIS KEMANUSIAAN: Menelaah Pemikiran Henry Bergson
}

\author{
Himyari Yusuf \\ IAIN Raden Intan Lampung \\ Himyar_yusuf@yahoo.com
}

\begin{abstract}
Abstrak
Dewasa ini sistem pengetahuan modern disadari telah menimbulkan implikasi yang tidak kondusif bagi manusia dan kemanusiaan. Karenanya pengembangan pengetahuan yang berbasis kemanusiaan sudah merupakan hal yang sangat penting untuk ditampilkan. Tulisan ini mencoba untuk mengkaji tentang apa dan bagaimana struktur fundamental pengetahuan manusia dalam pandangan Henry Bergson dan relevansinya bagi pengembangan pengetahuan yang berbasis kemanusiaan. Pendekatan yang digunakan bersifat filosofis dengan metode refleksi kritis. Henry Bergson menempatkan manusia dan kemanusiaan sebagai dasar dan sumber yang permanen dalam struktur pengetahuan manusia. Landasan ontologis, epistemologis dan aksiologis pengetahuan manusia adalah manusia dan kemanusiaan. Sarana dan sumber untuk mendapatkan pengetahuan adalah indra, akal, hati nurani atau intuisi. Sarana dan sumber-sumber pengetahuan tersebut bersifat sinergik atau saling menguatkan. Struktur pengetahuan manusia dalam pemikiran Bergson secara filosofis koheren dengan pengetahuan yang berbasis kemanusiaan. Pengetahuan yang berbasis kemanusiaan pada idealita juga harus menempatkan manusia dan kemanusiaan sebagai dasar, sumber dan tujuan yang paling fundamental.
\end{abstract}

\section{Abstract}

INITIATING HUMANITY-BASED KNOWLEDGE (Reviewing Henry Bergson's views). It has been realized that modern knowledge systems have stimulated a number of implications which are not conducive to human and humanity. Hence, the development of humanity-based knowledge is becoming a very important thing to be displayed. This paper 
attempts to examine the fundamental structure of human knowledge in the view of Henry Bergson and its relevance to the development of humanity-based knowledge. Henry Bergson puts humans and humanity as a basis and a permanent source of human knowledge structures. The cornerstone of the ontological, epistemological and axiological human knowledge is human and humanity. The means and the resources to gain knowledge, in his view, are: senses, reason, conscience or intuition. These three elements are synergistic or mutually reinforcing. The structure of human knowledge in Bergson's philosophical thought is coherent to the humanity-based knowledge which also puts human and humanity as its basis, sources and fundamental goals.

Kata Kunci : Struktur Pengetahuan; Kemanusiaan.

\section{A. Pendahuluan}

Pemikiran Bergson mengenai struktur pengetahuan sangat terkait dengan pandangannya tentang filsafat hidup, oleh karena itu untuk menggali hakikat pengetahuan Bergson dapat dan harus dirunut dalam filsafat hidup tersebut. The Liang Gie mengemukakan bahwa J.A. Leighion dalam karyanya "The Field of Philosophy" menjelaskan bahwa filsafat mencari suatu totalitas dan keserasian dari pengertian mengenai sifat dasar dan makna dari segala aspek suatu realitas. Karena itu suatu filsafat yang dianggap lengkap adalah yang mencakup suatu pandangan dunia mengenai seluruh kosmos, dan pandangan hidup (filsafat hidup) yang mengandung ajaran tentang nilai-nilai, makna-makna, dan tujuan-tujuan hidup manusia $^{1}$. Selain itu Loren Bagus mengemukakan bahwa filsafat hidup dalam bahasa sehari-hari mencakup tiga pengertian, satu di antaranya adalah cara atau pandangan hidup yang bertujuan mengatur seluruh aspek kehidupan manusia ${ }^{2}$.

Berkaitan dengan pengertian filsafat hidup tersebut di atas, dalam "Adat Lampung Pepadun dalam Tinjauan Filsafat Hukum" dijelaskan bahwa filsafat hidup atau pandangan hidup niscaya dibangun dengan berdasar pada nilai-nilai fundamental kemanusiaan, baik nilai-nilai yang bernuansa materialitas maupun nilai-nilai yang bernuansa spiritualitas. ${ }^{3}$ Tidak berbeda dengan

${ }^{1}$ The Liang Gie, Suatu Konsepsi Ke Arah Penertiban Bidang Filsafat, (Yogyakarta: Fakultas Filsafat UGM. 1979), h. 8.

${ }^{2}$ Loren Bagus, Kamus Filsafat, (Jakarta: Gramedia, 2000), h. 254.

${ }^{3}$ Himyari Yusuf, Adat Lampung Pepadun Dalam Tinjauan Filsafat 
pandangan tersebut, Achmadi juga mengemukakan bahwa filsafat hidup atau pandangan hidup pada hakikatnya jika dilihat dari aspek epistemologis adalah bersumber pada hakikat dan kodrat manusia. Filsafat hidup merupakan penjelmaan nilai-nilai manusia secara totalitas, sesuai hakikat manusia secara menyeluruh dan mendasar. Manusia yang menyeluruh dan mendasar adalah sentral dari seluruh realitas semesta yang kemudian menjadi sumber berbagai aliran filsafat, sehingga filsafat sebagai pandangan hidup (Weltsanschaung) niscaya dijadikan dasar setiap tindakan dan perbuatan manusia termasuk dalam penyelesaian berbagai problem kehidupan. ${ }^{4}$

Berbagai pandangan tersebut di atas, dapat direfleksikan bahwa filsafat hidup merupakan suatu formulasi dari pemikiran manusia yang mengandung muatan tentang bagaimana makna dan nilai-nilai, serta tujuan hidup manusia yang sesungguhnya, maka secara abstraktif, filsafat hidup korelatif dengan eksistensi dan esensi manusia secara holistik dan mendasar. Tentunya pemaknaan semacam ini juga menunjukkan bahwa manusia secara totalitas ditempatkan pada posisi paling strategis di antara makhluk-makhluk lainnya, karena itu bagaimanapun asumsi dan interpretasi tentang eksistensi dan esensi manusia, ia tidak akan pernah sama dengan makhluk lainnya yang hanya mempunyai kemampuan instinktif tanpa akal dan intuisi. Eksistensi dan esensi manusia yang totalitas bermakna bahwa manusia tidak dapat dipandang secara parsial fakultatif dengan hanya melihat salah satu dimensi dan potensinya saja sebagaimana yang terjadi pada belahan dunia Barat skuler. Sebab kesatuan dari keseluruhan dimensi dan potensi itulah yang secara hakiki dinamakan manusia.

Filsafat hidup atau pemahaman tentang nilai, makna dan tujuan hidup manusia pastinya sudah merupakan hal yang sangat mendesak untuk dikaji, dikretisasi, kemudian diaktualisasikan demi mempertahan kelangsungan hidup manusia dan kemanusiaan. Jika berpijak dari lingkup dan pengertian filsafat hidup di atas, maka dapat dipastikan bahwa keberadaan filsafat hidup akan membentuk dan mempengaruhi pola berpikir dan bertindak, berperilaku

Hukum,(Yogyakarta: Pascasarjana, Univ. Gajah Mada, 2004), h. 108.

${ }^{4}$ Asmoro Achmadi, Filsafat Umum, (Jakarta: Raja Grafindo Persada, 1997), h. 7-8. 
dan beraktivitas manusia, termasuk dalam hal pengembangan pengetahuan, ilmu pengetahuan dan teknologi, sehingga untuk membangun pengetahuan yang berbasis kemanusiaan tidak boleh tidak terlebih dahulu harus memahami filsafat hidup dimana pengetahuan bersangkutan akan dikembangkan. Karakteristik pengetahuan seperti itu sudah menjadi tumpuan dan harapan hidup manusia dewasa ini.

Filsafat hidup pada zaman modern muncul kembali sekitar tahun 1900. Pokok pesoalan yang diusung adalah memberikan prioritas kepada konsepsi kehidupan yang tidak semata-mata dalam bidang empiris praktis, tetapi juga dalam bidang teoritis filosofis dan melihat dasar nyata serta isi atau makna kenyataan dalam kehidupan manusia sebagai sesuatu yang dinamis dan berkembang. ${ }^{5}$ Menurut Achmadi, yang melatarbelakangi lahirnya filsafat hidup dalam era modern (abad ke-19 dan ke-20), adalah sebagai reaksi keras terhadap perkembangan ilmu pengetahuan dan teknologi yang demikian pesat. Perkembangan tersebut sangat mempengaruhi pola pikir manusia. Pada kenyataannya akal manusia hanya difungsikan untuk menganalisis sampai menyusun suatu sintesis baru. Alam semesta dan manusia dianggap sebagai mesin yang tersusun dari beberapa komponen materi dan bekerja sesuai dengan hukum-hukumnya. ${ }^{6}$ Secara faktual memang tidak dapat dipungkiri, bahwa pada abad ke-19 sampai awal abad ke-21, perkembangan ilmu pengetahuan dan teknologi melaju dengan pesat. Konsekuensinya perkembangan sektor industri juga melaju dengan tanpa hambatan. Fakta juga menunjukkan bahwa semua bentuk pemikiran manusia pada era tersebut ditujukan kepada hal-hal yang bersifat bendawi semata. Segala sesuatu yang ada di jagad semesta termasuk manusia dipandang sebagai mesin atau robot yang bersifat mekanik. Karena itu tulisan ini memfokuskan pembahasan pada bangunan filsafat hidup Henry Bergson abad ke-19, secara spesifik mengkaji dan menggali bagaimana sumber pengetahuan manusia menurut Bergson dan relevansinya bagi pengembangan pengetahuan yang berbasis kemanusiaan.

\footnotetext{
${ }^{5}$ Loren Bagus, Kamus.... h. 255.
}

${ }^{6}$ Achmadi, Filsafat...... h. 121. 


\section{B. Pengetahuan dan Problem Epistemologi}

Salah satu objek yang selalu menyibukkan para filosof sejak zaman awal hingga dewasa ini adalah persoalan pengetahuan manusia. Cabang filsafat yang secara khusus terkait dengan pertanyaan-pertanyaan tentang pengetahuan manusia disebut filsafat pengetahuan atau epistemologi. Oleh karena itu, mengkaji pengetahuan manusia dan unsur-unsur yang terkait dengannya tentu menjadi ranah atau kawasan epistemologi. Istilah epistemologi sendiri berasal dari bahasa Yunani yaitu "episteme" (pengtahuan) dan "logos" (ilmu) 7 . Dalam karyanya "Epistemologi Filsafat Pengetahuan" Hardono Hadi menjelaskan bahwa epistemologi atau filsafat pengetahuan adalah cabang filsafat yang mempelajari dan mencoba menentukan kodrat dan skop pengetahuan, pengandaianpengandaian dan dasarnya serta pertanggungjawaban atas pernyataan mengenai pengetahuan yang diselidiki. ${ }^{8}$

Dengan demikian epistemologi merupakan disiplin ilmu yang bersifat evaluatif, normatif dan kritis. ${ }^{9}$ Menurut Kattsoff, epistemologi atau filsafat pengetahuan, menyelidiki asal mula, susunan, metode dan keabsahan pengetahuan manusia ${ }^{10}$, sehingga persoalan epistemologi secara umum dapat dipadatkan menjadi persoalan yang berkaitan dengan validitas sumber-sumber pengetahuan dan pendekatan atau metode untuk mendapatkan pengetahuan, serta kreteria kebenaran suatu pengetahuan. Sesuai dengan itu Titus, Smith, Nolan, mengemukakan bahwa epistemologi dalam tampilannya mempunyai tiga persoalan pokok yaitu, 1) mengenai sumber-sumber pengetahuan; dari manakah pengetahuan yang benar itu datang dan bagaimana manusia mengetahuinya, 2) apakah watak atau karakter pengetahuan itu; apakah ada dunia yang di luar jangkauan pikiran manusia, dan ini adalah persoalan apa yang kelihatan dan hakikatnya, 3) apakah pengetahuan manusia itu valid dan bagaimana membedakan benar dan salah dalam arti memverifikasi tentang kebenaran ${ }^{11}$.

\footnotetext{
${ }^{7}$ J. Sudarminta, Epistemologi Dasar, (Yoyakarta: Kanisius, 2002), h. 18.

${ }^{8}$ P. Hardono Hadi, Epistemologi Filsafat Pengetahuan, (Yogyakarta: Kanisius,
} 1994), h. 5.

${ }^{9}$ J. Sudarminta, Epistemologi.... h. 18-19.

${ }^{10}$ Louis Kattsoff, Pengantar Filsafat, (Yogyakarta: Tiarawacana, 1992), h. 76.

${ }^{11}$ Titus, Smith, Nolan, Persoalan-Persoalan Filsafat, (Jakarta: Bulan Bintang, 
Persoalan krusial dan selalu diperdebatkan dalam epistemologi sampai dewasa ini adalah terkait dengan sumbersumber pengetahuan manusia. Dalam Essay Concerning Human Understanding John Locke (1632-1704) yang dikutip Zainuddin menjelaskan bahwa problem tentang sumber-sumber pengetahuan merupakan persoalan yang pertama dan fundamental dalam pengetahuan yang harus diselesaikan. Immanuel Kant (1724-1804) juga menempatkan problem yang sama, sehingga semenjak zaman Locke dan Kant inilah problem sumber pengetahuan mendapat tempat yang sangat penting dalam pembahasan-pembahasan filsafat. ${ }^{12}$ Problem sumber pengetahuan tersebut secara faktual terkait erat dan dapat dicermati dalam aliran-aliran epistemologi, yang pada kenyataannya setiap aliran mengklaim sumber pengetahuannya yang paling sahih, seperti aliran rasionalisme dan aliran empirisme. Kedua aliran ini menurut Zainuddin merupakan aliran paling pokok dalam epistemologi, karena aliran lainnya adalah perkembangan lebih lanjut dari kedua aliran tersebut ${ }^{13}$.

Sumber-sumber pengetahuan secara umum pada zaman modern meliputi empat sumber yaitu, kesaksian otoritas, akal, indra dan intuisi ${ }^{14}$. Dalam hal ini Amsal Bakhtiar, mengemukakan bahwa umumnya sumber pengetahuan meliputi, akal atau rasio, indra, intuisi dan Wahyu..$^{15}$ Sementara Al-Gazali salah satu pemikir Muslim, menetapkan sumber pengetahuan itu adalah akal, indra, dan hati atau intuisi. ${ }^{16}$ Sumber-sumber pengetahuan tersebut perlu dikemukakan secara garis besar bagaimana cara kerjanya masingmasing. Penjelasan ini dimaksudkan agar dapat dipahami bahwa semua sumber-sumber pengetahuan tersebut secara komtemplatif dan esensial bersifat sinergik atau korelatif satu dengan lainnya.

Akal atau rasio sebagai salah satu sumber pengetahuan dapat diidentikkan dengan istilah rasionalisme yang juga merupakan salah

1984), h. 187-188.

${ }^{12}$ Ibid, h. 197-198.

${ }^{13}$ M. Zainuddin, Filsafat Ilmu Perspektif Pemikiran Islam, (Yogyakarta: Banyu Media, 2003), h. 36.

${ }^{14}$ Titus, Smith, Nolan, Persoalan-Persoalan..., h. 203.

${ }^{15}$ Amsal Bakhtiar, Filsafat Ilmu, (Jakarta: Raja Grafindo, 2004), h. 98-110.

${ }^{16}$ M. Sholihin, Epistemologi Ilmu Dalam Pandangan Al-Ghazali, (Bandung: Pustaka Sakti, 2001), h.41. 
satu model pendekatan dalam epistemologi. Menurut Zainuddin rasionalisme dalam arti luas adalah suatu aliran filsafat modern yang dasar-dasarnya diletakkan oleh Rene Descartes, Spinoza dan Leibniz. Sedangkan dalam arti sempit rasionalisme adalah salah satu model pendekatan dalam epistemologi yang menempatkan akal atau rasio sebagai sumber dan sarana untuk mendapat pengetahuan. Untuk memperoleh kebenaran suatu pengetahuan harus dimulai dengan meragukan segala sesuatu kecuali aku sedang berpikir. "Cogito Ergo Sum" (aku berpikir maka aku ada). Kebenaran pengetahuan dalam pandangan Descartes adalah apa yang jelas dan terpilah-pilah (clear and distintly). ${ }^{17}$

Rasionalisme mengandaikan bahwa ide tentang kebenaran sebenarnya sudah ada dan pemikiran manusia mampu untuk mengetahui ide kebenaran itu, dan tidak menciptakannya, tidak pula mempelajarinya lewat pengalaman. Dengan istilah lain ide kebenaran yang menjadi dasar dan sumber pengetahuan diperoleh lewat berpikir secara rasional dan terlepas dari pengalaman manusia. Sistem pengetahuan rasionalisme dibangun secara kohern di atas landasan yang sudah pasti, dan generalisasi pengetahuannya dengan logika deduktif yang bersifat $a$ priori. ${ }^{18}$ Berbeda dengan aliran rasionalisme, aliran yang meletakkan indra sebagai sumber pengetahuan dapat diidentikkan dengan aliran empirisme. Aliran ini mengandaikan bahwa manusia memperoleh pengetahuan harus melalui pengalaman indrawi. John Locke seorang bapak empirisme Inggris mengemukakan bahwa pada waktu manusia dilahirkan akalnya seperti buku catatan kosong (tabula rasa) dan buku catatan kosong itu akan diisi oleh pengalaman-pengalaman indrawi, sehingga pengetahuan yang benar adalah yang bersumber dan diperoleh melalui pengalaman indrawi manusia ${ }^{19}$, bahkan empirisme radikal menganggap pengetahuan yang benar hanyalah pengetahuan yang dapat dilacak sampai pada pengalaman indrawi, dan jika tidak dapat dilacak seperti itu bukanlah pengetahuan yang benar. $^{20}$

${ }^{17}$ M. Zainuddin, Filsafat Ilmu..... h. 36-37.

${ }^{18}$ Jujun S., Пlmu Dalam perspektif Sebuah Karangan Tentang Hakikat Пmu, (Jakarta: Obor Indonesia, 2001), h. 10.

${ }^{19}$ Louis Kattsoff, Pengantar Filsafat... h. 136-137.

${ }^{20} \mathrm{Ibid}, \mathrm{h} .138$. 
Aliran ini hanya menekankan kemampuan manusia dalam persepsi atau pengamatan atau apa yang diterima indra dari lingkungan alam. Pengetahuan ini diperoleh dengan membentuk ide-ide sesuai dengan fakta yang diamati, sehingga yang dapat diketahui hanya apa yang didapat dari indra manusia. ${ }^{21}$ Dengan demikian empirisme mengklaim pengetahuan yang benar hanyalah yang dapat dibuktikan dengan fakta pengalaman manusia, dan dengan metode induktif yang mengeneralisasi kasus-kasus yang khusus menjadi pengetahuan yang bersifat umum (a posteriori). ${ }^{22}$

Pengetahuan yang bersumber pada akal dan indra atau rasionalisme dan empirisme, keduanya dapat diasumsikan sebagai induk produk sebuah rangkaian penalaran. Berbeda halnya dengan sumber pengetahuan intuisi. Menurut Jujun, pengetahuan yang bersumber pada intuisi diperoleh melalui cara tertentu. Misalnya, seseorang yang sedang terpusat pikirannya terhadap suatu masalah, tiba-tiba saja menemukan jawaban atas permasalahan yang sedang ia pikirkan (metode kontemplasi). Pengetahuan intuitif dapat dipergunakan sebagai hipotesis bagi analisis selanjutnya dalam menemukan benar tidaknya pernyataan yang dikemukakan, dengan demikian kegiatan intuitif dan analitis dapat bekerja saling membantu untuk menemukan suatu kebenaran pengetahuan, maka dari itu Maslow dan Nietsche menempatkan intuisi sebagai pengalaman puncak dan intelegensi yang paling tinggi. ${ }^{23}$

Ketiga sumber pengetahuan di atas, sangat berbeda dengan pengetahuan yang bersumber dari wahyu. Menurut Andi Hakim, wahyu merupakan sumber pengetahuan yang disampaikan Tuhan kepada manusia. Tuhan menurunkan sebagian ilmu-Nya melalui Wahyu (Naqliyah) atau ilmu yang diturunkan. Pengetahuan ini adalah kumpulan petunjuk Tuhan yang membimbing manusia bagaimana harus bertindak. ${ }^{24}$ Hakim bahkan mengkritik pengetahuan yang bersumber pada akal dan indra. Menurutnya pengetahuan yang bersumber pada akal dapat mengalami salah, demikian pula halnya

${ }^{21}$ Titus, Smith, Nolan, Persoalan-Persoalan.... h. 200.

${ }^{22}$ Jujun S, Filsafat Пmu Sebuah Pengantar Populer, (Jakarta : Sinar Harapan, 1993), h. 51.

${ }^{23} \mathrm{Ibid}$, h. 53.

${ }^{24}$ Andi Hakim Nasution, Pengantar Ke Filsafat Sains, (Bogor : Pustaka Litera Antar Nusa, 1999), h. 21. 
pengetahuan yang bersumber pada indra mungkin saja mengalami penyimpangan. Sedangkan pengetahuan yang bersumber pada wahyu merupakan pengetahuan yang berada pada taraf haqqul yaqin atau pengetahuan yang benar-benar shahih karena sumbernya adalah petunjuk Tuhan. ${ }^{25}$

Berbagai pandangan tentang pengandaian sumber pengetahuan di atas, menimbulkan suatu perenungan yang sangat mendasar. Karena masing-masing mengklaim seakan alirannya yang paling benar, sehingga problemnya adalah bagaimana mensejajarkan sumber-sumber pengetahuan tersebut agar merupakan satu kesatuan, atau paling tidak saling bersinergik satu dengan lainnya. Merunut kembali apa yang telah dijelaskan sebelumnya bahwa yang menjadi kajian dalam tulisan ini adalah pengetahuan manusia. Jika pengetahuan manusia, maka idealnya persoalan-persoalan pengetahuan harus dijumbuhkan kepada empunya yaitu manusia dan tentunya manusia yang dipandang secara menyeluruh dan utuh. Menyeluruh artinya semua potensi yang melekat pada diri manusia merupakan struktur bangunan yang tak terpisahkan, bersinergik satu sama lainnya. Sedangkan utuh artinya manusia harus dipandang dari unsur sampai kepada hakikatnya yang paling hakiki, bukan manusia bertubuh tanpa roh atau sebaliknya manusia punya roh tanpa tubuh. Karena secara esensial manusia bukanlah mesin atau robot yang hanya tersusun dari bagian-bagian materi semata seperti yang dipahami oleh Barat sekuler. Jika manusia disamakan dengan mesin atau dipandang sebagai yang tersusun dari bagian-bagian materi belaka, maka secara filosofis manusia telah meruntuhkan derajat dan martabat kemanusiaannya sendiri. Dengan demikian gagasan tentang pengetahuan yang berbasis kemanusiaan secara ontologis, epistemologis dan aksiologis adalah manusia dan kemanusiaan atau yang disebut pengetahuan dari manusia, oleh manusia dan untuk manusia.

\section{Mengenal Henry Bergson}

Henry Bergson lahir di Paris pada tanggal 18 Oktober 1859. Ayahnya adalah seorang Yahudi Polandia dan ibunya adalah wanita Yahudi kelahiran Inggris Utara. Sejak kecil Bergson tertarik

${ }^{25}$ Ibid. 
pada pelajaran matematika dan sastra, tetapi setelah dewasa ia mempelajari sastra dan biologi dan kemudian filsafat. ${ }^{26}$ Pada masa melanglang buana ke berbagai daerah dan negara, tahun 1900 Bergson mendapat anugerah Chair pada College de France. Tahun 1911 ia mengunjungi Inggris dan memberi kuliah di Birmingham Oxford. Tahun 1914 Bergson dipilih menjadi anggota Academie Francaise. Kemudian pada tahun 1927 ia mendapatkan hadiah Nobel bidang literature ${ }^{27}$. Bergson terkenal dan berpengaruh di Prancis dan juga di luar Francis kaitannya dengan gagasannya tentang filsafat hidup dan ajarannya mengenai élan vital atau kekuatan kehidupan yang sentrifugal serta evolution creative atau dorongan kreatif perkembangan. ${ }^{28}$ Dalam buku Filsafat Barat Kontemporer, Jilid II K. Bertens menjelaskan yang tak dapat disangkal pada Bergson ialah bahwa ia mempunyai erudisi yang amat luas. Bergson mengenal secara mendalam baik ilmu pengetahuan alam maupun ilmu pengetahuan kemanusiaan. Berkaitan dengan ilmu pengetahuan itu salah satu faktor yang mengakibatkan filsafatnya jadi populer. ${ }^{29}$ Ditambahkan pula bahwa Bergson sangat menguasai sejarah filsafat dan ia sangat menaruh pertahatian khusus pada Plotinos, serta pemikiran Bergson sendiri sangat akrab dengan tradisi spiritualisme Prancis, terutama Maine de Biran (1766-1824). ${ }^{30}$ Pada akhirnya filosof Prancis yang sangat populer ini meninggal dunia pada tanggal 3 Januari $1941 .^{31}$

\section{Sumber Pengetahuan Manusia Dalam Pemikiran Bergson}

Berdasarkan uraian sebelumnya, dipahami bahwa pemikiran filosofis Bergson sangat luas dan mendalam. Ia tidak hanya memusatkan perhatiannya pada hal-hal yang konkret saja, tetapi menjangkau hal-hal yang bersifat metafisik. Bahkan

${ }^{26}$ Djuretna, A, Moral dan Relegi Menurut Emile Durkheim dan Henry Bergson,(Yogyakarta : Kanisius, 1994), h. 85.

${ }^{27}$ Diane Collinson, Lima Puluh Filosof Dunia Yang Menggerakkan, (Jakarta: Raja Grafindo Persada, 2001), h. 192-193.

${ }^{28}$ Loren Bagus, Kamus.... h. 255.

${ }^{29}$ K. Bertens, Filsafat Barat Kontemporer, Jilid II, (Jakarta : Gramedia Pustaka Utama, 2001), h. 11

${ }^{30} \mathrm{Ibid}$.

${ }^{31} \mathrm{Ibid}, \mathrm{h} .12$. 
Bergson memberikan kritik yang sangat tajam terhadap ontologi materialisme dan epistemologi Positivisme, karena kedua aliran ini terlalu mengabaikan dimensi metafisika dalam sistem filsafat. Dalam buku "Materi dan Ingatan" yang dikutip oleh Bertens, Bergson mempelajari hubungan antara jiwa dan tubuh, antara roh dan materi. Menurut Bertens, pendirian Bergson yang termuat dalam buku tersebut pada dasarnya bersifat dualistis (suatu ontologi dualisme moderat), karena Bergson mempertahankan materi dan roh sebagai kenyataan. Bergson sangat menolak monisme yang mereduksikan manusia kepada satu unsur saja, baik roh kepada materi, maupun materi kepada roh, karena roh tidak dapat berkerja dan berpikir tanpa tubuh. ${ }^{32}$

Pemahaman yang dapat disarikan dari penjelasan di atas, bahwa dasar ontologi dalam pemikiran Bergson ialah dualisme, akan tetapi dualisme moderat yang mengakui adanya roh dan tubuh yang keduanya dapat berinteraksi atau bersinergi (bukan bersatu). Atas dasar itulah maka dapat dipahami jika Bergson memberikan kritik yang cukup tajam terhadap pengetahuan yang monistik, dan sistem pengetahuan positivistik yang anti metafisik. Bergson menyelidiki problem tersebut melalui studi mengenai ingatan. Menurut Bergson ingatan paling jelas dan tampak sebagai titik interaksi antara roh dan materi. Ingatan dibedakannya menjadi dua macam, yaitu ingatan yang terdiri atas mekanisme-mekanisme motoris yang mirip dengan kebiasaan-kebiasan. Ingatan ini hanya merupakan disposisi badani untuk menjawab suatu rangsangan dengan cara tertentu dan pada sisi ini tidak terlihat unsur rohani apapun. ${ }^{33}$ Sedangkan ingatan lainnya adalah "ingatan murni". Ingatan ini membentuk dan merekam angan-angan tentang setiap kejadian dalam hidup manusia tanpa mengabaikan satu detailpun. Ingatan dalam arti ini bersifat rohani. Ingatan murni berhubungan erat dengan otak. Sedangkan fungsi otak adalah mengadakan seleksi. Oleh karena itu melalui otak, manusia memilih kenangan-kenangan yang berguna untuk praksis, maka dalam praktek kehidupan konkret kedua jenis ingatan itu terdapat bersama-sama, namun tetap harus dibedakan agar tidak terjebak ke arah materialisme. ${ }^{34}$

${ }^{32}$ Ibid, h. 14.

${ }^{33}$ Ibid, h. 15.

${ }^{34}$ Ibid, h. 15-16. 
Elan Vital adalah suatu kekuatan atau daya kreatif yang termanifestasi dalam kehidupan manusia, sehingga manusia dapat berada dalam posisi yang bebas, namun bukan berarti bebas yang tanpa batas. Dalam konteks ini menurut Bergson ada beberapa kekuasaan jiwa manusia, antara lain kekuasaan Inteligensi dan Intuisi. ${ }^{35}$ Nampaknya kedua kekuasaan inilah yang menjadi kunci dalam memahami sumber pengetahuan dalam pemikiran Bergson. Inteligensi merupakan kegiatan dari suatu organisme dalam menyesuaikan diri dengan situasi-situasi. Penyesuaiannya dengan menggunakan kombinasi fungsi-fungsi seperti persepsi, ingatan, konseptualisasi, abstraksi, imajinasi, konsentrasi, seleksi, relasi, rencana, prediksi, memilih dan mengarahkan. Menurut Bergson inteligensi adalah sesuatu yang menempatkan manusia sebagai makhluk tertinggi dibanding makhluk-makhluk lainnya. Inteligensi atau akal budi manusia terarah pada benda-benda fisis dan yang menjadi objek akal budi ialah apa yang tidak kontinue dan apa yang tidak bergerak. ${ }^{36}$ Dalam melakukan analisis, akal budi memotongmotong suatu objek ke dalam unsur-unsurnya; dengan membentuk konsep-konsep ia membekukan realitas menjadi keseluruhan yang statis. Pengandaian seperti itu menurut Bergson sama dengan yang dilakukan oleh para ilmuan yang berusaha mereduksikan makhluk hidup kepada unsur-unsur fisis dan kimiawi. Jadi biarpun sangat cocok untuk berpraksis dan menguasai dunia (termasuk manusia sendiri sejauh menjadi objek ilmu pengetahuan), akal budi tidak dapat menangkap realitas kehidupan yang sesungguhnya dan kreativitas yang memadai (élan vital). ${ }^{37}$

Dengan demikian dapat dipahami bahwa menurut Bergson inteligensi atau akal budi hanya mampu sejauh mengenai pengetahuan bendawi saja. Ia dapat meraih pemikiran konseptual dan diskursif, ia mampu menganalisis persoalan secara ilmiah. Oleh karena itu akal budi tiada lain adalah fungsi praktis oprasional pikir manusia. Selain itu dapat dipahami pula bahwa Inteligensi mempunyai maksud khusus, yaitu membuat manusia mampu menguasai benda-benda dalam alam, sehingga menurut

\footnotetext{
${ }^{35}$ Loren Bagus, Kamus... h. 359.

${ }^{36}$ K. Bertens, Filsafat Barat.... h. 19-20.

${ }^{37}$ Ibid.
} 
Bergson inteligensi atau akal budi merupakan perpanjangan indra manusia dan berfungsi menciptakan serta menggunakan alat-alat, memikirkan penggunaan benda-benda bagi kelangsungan hidup, namun kemampuannya hanya tertuju pada benda tertentu saja. ${ }^{38}$

Harun Hadiwijono dalam buku Sari Sejarah Filsafat Barat 2, lebih menegaskan bahwa bagi Bergson manusia memiliki akal budi, yaitu kecakapan untuk menciptakan alat-alat kerja untuk dirinya dan secara bebas dapat mengubah-ubah pembuatan alat-alat kerja itu. Akal budi mencakapkan manusia untuk menyadarkan dirinya akan kepentingan individu-individu. Akan tetapi akal budi tidak dapat dipakai untuk menyelami hakikat yang sebenarnya dari segala kenyataan. Akal budi memiliki fungsi yang praktis dan tidak dapat menyelami hakikat yang sebenarnya dari segala kenyataan. ${ }^{39}$ Jika dalam pengandaian-pengandaian Bergson di atas, menyebutkan bahwa inteligensi atau akal budi manusia merupakan perpanjangan dari indra, maka dapat dipahami bahwa indra dan inteligensi atau akal budi bersifat korelatif dan juga mempunyai kedudukan dan fungsi yang penting dalam struktur pemikiran Bergson. Namun keduanya tidak mempunyai kemampuan untuk mengetahui sampai kepada hakikat realitas atau kenyataan. Dengan demikian Bergson dipastikan tidak mereduksi indra ke dalam intelegensi atau akal, tetapi mendudukkan keduanya sebagai mitra yang bersifat saling menguatkan atau bersinergik satu dengan lainnya.

Selain kekuasaan indra dan akal budi, manusia juga memiliki kekuasaan intuisi. Jika akal budi berkiblat kepada materi, maka intuisi secara istimewa terarah pada yang immateri. Namun dalam kerjanya ada hubungan timbal balik antara akal budi dan intuisi, karena keduanya saling membutuhkan. Intuisi tidak mungkin berada tanpa akal budi, sebagaimana roh tidak mungkin berada tanpa materi. ${ }^{40}$ Intuisi dapat menyelami hakikat dari segala kenyataan, yaitu suatu tenaga rohani, suatu kecakapan yang dapat melepaskan diri dari akal, kecakapan untuk menyimpulkan serta meninjau dengan sadar. Intuisi adalah suatu bentuk pemikiran

${ }^{38}$ Djuretna, Moral dan.... h. 93.

${ }^{39}$ Harun Hadiwijono, Sari Sejarah Filsafat Barat 2, (Yogyakarta: Kanisius, 1991), h. 137.

${ }^{40}$ K. Bertens, Filsafat Barat.... h. 20. 
yang berbeda dengan pemikiran akal sebab pemikiran intuisi bersifat dinamis. Fungsi intuisi yang paling mendasar adalah untuk mengenal hakikat pribadi dan hakikat seluruh kenyataan. ${ }^{41}$

Harry Hamersma dalam bukunya Tokoh-Tokoh Filsafat Barat Modern, menjelaskan bahwa intuisi merupakan milik eksklusif manusia. Berkat intuisinya dunia terbuka untuk menusia. Intuisi adalah kekuatan yang terus-menerus mendorong manusia untuk memperbaharui pola-pola yang statis. ${ }^{42}$ Menurut Juretna mengatakan bahwa menurut Bergson rasio hanya sebagai salah satu unsur saja dari kekuasaan jiwa manusia dan terbatas pada hal-hal mekanistis dan determinatif yang pasti dan telah ada. Untuk sampai pada kedalaman realitas, bukanlah rasio yang bertindak melainkan intuisi. $^{43}$ Penjelasan mengenai kedudukan dan fungsi intuisi tersebut, dapat dimengerti bahwa intuisi dalam pandangan Bergson merupakan sentral fundamental dalam pengetahuan manusia. Dengan kekuasaan intuisi inilah manusia dapat membebaskan diri dari cengkraman material dan mampu menembus kepada hakikat segala sesuatu. Dengan demikian inteligensi atau akal budi merupakan perpanjangan dari indra dan intuisi adalah potensi untuk mengetahui hakikat segala sesuatu. Ketiga potensi dasar tersebut bagi Bergson merupakan sumber pengetahuan manusia yang bersifat sinergik satu dengan lainnya tidak ada yang tereduksi. Dengan kata lain indra menjadi bahan kerja akal budi yang bekerja pada tatanan fisik material, kemudian intuisi meneruskan pada tatanan yang immateri untuk menangkap hakikat dari seluruh kenyataan semesta.

\section{E. Sketsa Pengembangan Pengetahuan Berbasis Kemanusiaan}

Fakta historis pengetahuan manusia berkembang sejalan dengan tampilan isme-isme yang nampak dalam aliran-aliran epistemologi. Misalnya aliran rasionalisme dan empirisme. Kedua aliran besar ini telah berhasil menghantarkan kemajuan-kemajuan yang sangat signifikan, spesifik dalam bidang ilmu pengetahuan

${ }^{41}$ Harun Hadiwijono, Sari Sejarah.... h. 137.

${ }^{42}$ Harry Hamersma, Tokoh-Tokoh Filsafat Barat Modern, (Jakarta: Gramedia, 1986), h. 105.

${ }^{43}$ Djuretna, A, Moral dan..... h. 10. 
dan teknologi yang demikian pesat dan spektakuler. Namun disisi lain yang tidak dapat dipungkiri oleh siapapun, bahwa kemajuankemajuan tersebut telah berbagai problem bagi kehidupan manusia. ${ }^{44}$ Seperti disinyalir oleh Budi Hardiman, bahwa pengetahuan Barat skular, telah banyak menimbulkan problematika yang sangat mendasar bagi kehidupan manusia, karena pengetahuan mereka telah kehilangan tujuan yang sebenarnya. Skularisasi pemikiran dan pengetahuan telah melahirkan pandangan yang serba mekanistik mengenai realitas dan pandangan dunia yang tidak ada tempat bagi roh dan nilai-nilai kerohanian. Tidak berbeda dengan Hardiman, C.A. Qodir mengemukakan bahwa salah satu hal yang menimbulkan dikotomi tentang manusia dalam peradaban Barat skuler adalah berawal dari persoalan hubunan roh dan tubuh (persoalan ontologi). Descartes misalnya memberikan kepada roh dan tubuh sifat-sifat yang saling bertentangan secara mendasar, yang satu mempunyai kesadaran dan keluasan dan yang lainnya tidak, maka timbullah masalah roh dan tubuh yang tidak dapat hidup bersama ${ }^{45}$. Dalam upaya memecahkan persoalan ontologism tersebut, sebagian filosof Barat mereduksikan ke dalam salah satunya, apa roh menjadi tubuh atau sebaliknya. Namun karena sebagian besar filosof Barat adalah skuler, maka mereka lebih cenderung kepada ontologi monisme materialisme yang memandang manusia sebagai tubuh tanpa roh. Konsekuensinya manusia menjadi tidak berbeda dengan mesinmesin yang harus diawasi dengan kekuatan fisis-kimiawi dan alatalat teknologi.

Pandangan kedua pakar di atas, dipertegas lagi oleh Henryk Skolimowski, bahwa antara tahun 1700 hingga 1900, manusia memisahkan pengetahuan dari esensi nilai-nilainya, dari persoalanpersoalan transendentalnya, akhirnya pengetahuan menjadi terasing. Keterasingan ini pada gilirannya menjadi keterasingan manusia; manusia memisahkan dirinya sendiri dari pengetahuannya maupun nilai-nilainya, sehingga tak ada lagi kesatuan manusia dengan pengetahuan dan nilai-nilainya. ${ }^{46}$ Uraian-uraian di atas,

${ }^{44}$ Budi Hardiman, Melampaui Postivisme dan Modernisme, (Yogyakarta: Kanisius, 2003), h. 21.

${ }^{45}$ C.A. Qodir, Filsafat dan Ilmu Pengetahuan Dalam Islam, Terj.Hasan Basri, (Jakarta: Obor Indones, 1989), h. 2-3.

${ }^{46}$ Henryk Skolimowski, Filsafat Lingkungan, Merancang Taktik Baru untuk 
secara reflektif menunjukkan bahwa problem pengetahuan dan kemanusiaan pada dasarnya bermula dari persoalan ontologis, kemudian berimplikasi kepada epistemologis dan aksiologis. Ketiga landasan dasar pengetahuan tersebut secara falsafati niscaya searah, seiring dan sejalan atau linier. Misalnya ontologi monisme materialisme dapat dipastikan bahwa aspek epistemologinya adalah yang bersifat materialistis dan cenderung anti metafisis, dan aspek aksiologinya juga dapat dipastikan hanya bersifat pragmatis. Dengan demikian, paradigma pengetahuan ilmiah yang telah melahirkan teknologi spektakuler dewasa ini sudah saatnya untuk dikembalikan kepada empunya yaitu manusia dan kemanusiaan dengan segala nilai-nilai yang membingkai kehidupan manusia, sesuai dengan hakikat, kedudukan dan fungsi pengetahuan manusia yang sesungguhnya.

Sebagaimana telah dikemukakan, bahwa hakikat dan tujuan pengetahuan manusia adalah untuk mengembangkan dan menyempurnakan serta memenuhi berbagai kebutuhan kehidupan manusia, maka berbagai dimensi dan potensi manusia merupakan dasar fundamental bagi eksistensi dan esensi pengetahuan. Dalam hal ini Sudarminta menjelaskan bahwa dalam interaksinya dengan dunia dan lingkungan sekitarnya, manusia sangat membutuhkan pengetahuan, maka memperoleh pengetahuan merupakan bagian hakiki dari cara beradanya manusia (Knowing is a mode of being) ${ }^{47}$. Muthahhari dalam "Goal of Life" mengemukakan bahwa, kesempurnaan hidup manusia sangat tergantung pada pengetahuannya, maka bagi para filosof, kesempurnaan manusia adalah konteks umum dari pengetahuannya tentang realitas secara menyeluruh dan mendasar, sebagaimana misi kenabian yang diutus oleh Tuhan kepada ummat manusia adalah untuk memberikan pengetahuan dan pemahaman tentang realitas. Dengan pengetahuan itulah manusia memperoleh petunjuk untuk melakukan apa yang diinginkan. ${ }^{48}$ Charris Zubair juga menjelaskan bahwa pengetahuan yang kemudian berkembang menjadi ilmu merupakan upaya manusia untuk mengungkapkan dan menyibak tabiryang menutupi

Menjalani Kehidupan, Terj. Saut Pasaribu, (Yogyakarta: Bentang Budaya, 2004), h. 2122.

${ }^{47}$ J. Sudarminta, Epistemologi.... h. 43.

${ }^{48}$ Murtadha Muthahhari, Mengapa Kita Diciptakan, Terj. M. Al-Mandary, (Jakarta: Pustaka Zahra, 2003), h. 88 dan 30. 
realitas. Bagi manusia, misteri realitas harus terungkap sebab hanya dengan demikian eksistensi kemanusiaannya menjadi jelas. ${ }^{49}$ Dengan demikian dapat dipahami bahwa antara pengetahuan dan kemanusiaan merupakan dua sisi mata uang, satu dengan lainnya saling kait mengkait dan saling memperjelas. Tegasnya, jika tanpa pengetahuan maka eksistensi manusia dan kemanusiaan tidak dapat diketahui secara tepat. Sebaliknya, tidak akan ada manusia dan kemanusiaan, jika tanpa pengetahuan.

Urgensitas keterkaitan pengetahuan dan hakikat kemanusiaan, dikemukakan juga oleh Skolimowski, bahwa pengetahuan bukanlah simpanan informasi yang sia-sia, tetapi suatu daya vital yang menopang kehidupan pada segenap level eksistensi manusia dan kemanusiaan ${ }^{50}$. Oleh karena itu proses penyatuan dan kebangkitan kembali sifat universal dan hakikat pengetahuan, kesatuan kehidupan dengan pengetahuan, harus segera diupayakan dan segera diwujudkan. Skolimowski menambahkan bahwa penyatuan kembali pengetahuan dengan nilai-nilai kemanusiaan, bukanlah karena ada inters atau tendensi tertentu, tetapi untuk menjamin keberlangsungan kemanusiaan itu sendiri. Kita harus memulihkan kesatuan pengetahuan dengan nilai-nilai kemanusiaan, kita harus insaf bahwa pengetahuan yang tercerahkan (enlightened knowledge) adalah kunci bagi makna kemanusiaan. ${ }^{51}$

Merunut kembali pandangan Bergson, bahwa pengetahuan manusia secara ontologis, epistemologis dan aksiologis adalah manusia dan kemanusiaan. Dengan demikian, sebagaimana telah dikemukakan sebelumnya bahwa hakikat pengetahuan adalah dari manusia, oleh manusia dan untuk memanusiawikan manusia, dalam arti manusia dan nilai-nilai kemanusiaannya. Paradigma pengetahuan seperti itu niscaya mendudukkan semua potensi dasar manusia menjadi sumber pengetahuan. Berbagai potensi dasar manusia, seperti indra, akal dan hati atau intuisi semuanya ditempatkan sebagai yang bersinergik, saling menguatkan satu

${ }^{49}$ A. Charris Zubair, Dimensi Etik dan Asketik Ilmu Pengetahuan Manusia, Kajian Filsafat Пmu, (Yogyakarta: LESFI, 2002), h. 18.

${ }^{50}$ Skolimowski, Filsafat Lingkungan ... h. 26.

${ }^{51}$ Ibid, h. 29. 
sama lainnya dan tidak ada yang tereduksikan. ${ }^{52}$ Charris Zubair dalam pembahasannya tentang alat manusia untuk mengungkap dan menangkap realitas, menyimpulkan bahwa "alat yang dipakai untuk memahami kebenaran dan untuk mengembangkan pengetahuan ilmiah, tidak sekedar berupa rasionalitas manusia, melainkan seluruh potensi kemanusiaan harus secara sungguhsungguh dioptimalisasikan, dan yang disebut ilmiah, bukan hanya yang bersifat rasional dan empiris saja, melainkan juga yang melibatkan imajinasi-intuisi dan hati nurani. ${ }^{53}$

\section{F. Penutup}

Filsafat hidup Henry Bergson menempatkan manusia dan kemanusiaan sebagai dasar dan sumber yang permanen dalam struktuk pengetahuan manusia. Landasan atau dasar ontologis, epistemologis dan aksiologis pengetahuan manusia adalah manusia dan kemanusiaan. Artinya sarana dan sumber untuk mendapatkan pengetahuan adalah seluruh potensi yang membingkai eksistensi manusia, yaitu indra, akal, hati nurani atau intuisi. Sarana dan sumber-sumber pengetahuan tersebut saling menguatkan.

Struktur pengetahuan manusia dalam pemikiran Bergson secara filosofis koheren dengan pengetahuan yang berbasis kemanusiaan. Pengetahuan yang berbasis kemanusiaan pada idealita juga harus menempatkan manusia dan kemanusiaan sebagai dasar dan sumber serta tujuan yang paling fundamental. Dengan kata lain; paradigma pengetahuan berbasis kemanusiaan adalah dari manusia, oleh manusia dan untuk memanusiawikan manusia. Pastinya manusia yang dipandang secara holistik dan mendasar. []

${ }^{52}$ Lihat juga Hadari Nawawi, Hakikat Manusia dalam Islam, (Surabaya: AlIkhlas, 1993).

${ }^{53}$ Zubair, Dimensi Etik ..... h. 30. 


\section{Daftar Pustaka}

Achmadi, Asmoro, Filsafat Umum, Jakarta: Raja Grafindo Persada, 1997.

Bertens, K., Filsafat Barat Kontemporer II, Jakarta, Gramedia, 2001.

Bagus, Loren, Kamus Filsafat, Jakarta: Gramedia Pustaka Utama, 2000.

Collinson, Diane, Lima Puluh Filosof Dunia yang Menggerakkan, Yogyakarta: Kanisius, 2001.

Djuretna, A. , Moral dan Religi Menurut Emile Duekheim dan Henri Bergson, Yogyakarta: Kanisius, 1994.

Gie, The Liang, Suatu Konsepsi ke Arah Penertiban Bidang Filsafat, Yogyakarta, Fakultas Filsafat UGM, 1979.

Hadiwijono, Harun, Sari Sejarah Filsafat Barat 2, Yogyakarta: Kanisius, 1991.

Hadi, P. Hardono, Epistemologi Filsafat Pengetahuan, Yogyakarta, Kanisius, 1994.

Hakim, Andi N. , Pengantar Ke Filsafat Sains, Bogor: Pustaka Litera, 1999.

Hardiman, Budi F., Melampaui Positivisme dan Modernisme, Yogyakarta: Kanisius, 2003.

Kattsoff, Louis, Pengantar Filsafat, Yogyakarta: Tiarawacana, 1992.

Muthahhari, Murtadha, Mengapa Kita Diciptakan, Terj. AlMandary,Jakarta,Pustaka Zahra, 2003.

Nawawi, Hadari, Hakikat Manusia Menurut Islam, Surabaya: al-Ikhlas, 1993.

Suriasumantri, Jujun S, Filsafat Ilmu Sebuah Pengantar Populer, Jakarta: Sinar Harapan, 1987.

Sholihin, M., Epistemologi Ilmu Dalam Pandang Al-Ghazali, Bandung: Pustakasakti, 2001.

Skolimowski, Henry, Filsafat Lingkungan, Merancang Taktik Baru untuk Menjalani Kehidupan, Terj. Saut Pasaribu, Yogyakarta: Bentang Budaya, 2004.

Smith, Titus, Nolan, Persoalan-persoalan Filsafat, Jakarta, Bulan Bintang, 1984. 
Sudarminta, J., Ilmu Dalam Perspektif Sebuah Karangan Tentang Hakikat Ilmu, Jakarta: Obor Indonesia, 2001. , Epistemologi Dasar, Yogyakarta, Kanisius, 2002.

Yusuf, Himyari, Adat Lampung Pepadun Dalam Tinjauan Filsafat Hukum, Yogyakarta: Pascasarjana UGM, 2004.

Zainudin, M. , Filsafat Ilmu Perspektif Pemikiran Islam, Yogyakarta: Banyu Media, 2003.

Zubair, Ahmad Charris, Dimensi Etik dan Asketik Ilmu Pengetahuan Manusia, Kajian Filsafat Ilmu, Yogyakarta: LESFI, 2002. 